\title{
Corn and Soil Response to a Recently Developed Pelletized Papermill Biosolids
}

\author{
Morteza Mozaffari, Hannah C. Hays \\ Northeast Research and Extension Center, Department of Crop Soils and Environmental Science, University of Arkansas System
} Division of Agriculture, Fayetteville, USA

Email: mmozaff@uark.edu

How to cite this paper: Mozaffari, M. and Hays, H.C. (2019) Corn and Soil Response to a Recently Developed Pelletized Papermill Biosolids. Agricultural Sciences, 10, 1581-1591.

https://doi.org/10.4236/as.2019.1012116

Received: January 2, 2019

Accepted: December 14, 2019

Published: December 17, 2019

Copyright (c) 2019 by author(s) and Scientific Research Publishing Inc. This work is licensed under the Creative Commons Attribution-NonCommercial International License (CC BY-NC 4.0). http://creativecommons.org/licenses/by-nc/4.0/

\section{cc) (7) (8) Open Access}

\section{Abstract}

Beneficial utilization of industrial byproducts such as papermill biosolids $(\mathrm{PB})$ provides a unique opportunity to reduce the overall production cost and increase environmental sustainability. Pelletization of a byproduct enhances its marketability by improving the transportation and application. This greenhouse study was conducted to gain a better understanding of the properties and effects of, a recently developed pelletized papermill biosolids (PPB), on corn (Zea mays L.) and soil. Urea and PPB were each applied at four total $\mathrm{N}$ rates equivalent to $45,90,135$, and $180 \mathrm{~kg} \cdot \mathrm{ha}^{-1}$ and an additional control treatments of 0 was also included. The PPB contained 379 and $14 \mathrm{~g} \cdot \mathrm{kg}^{-1}$ total $\mathrm{N}$ and $\mathrm{C}$ and its $\mathrm{C}: \mathrm{N}$ ratio was 27 . Nitrogen treatment significantly $(P<$ 0.0001 ) influenced corn dry biomass, $\mathrm{N}$ concentration, and $\mathrm{N}$ uptake. Corn dry biomass ranged $26.9-41.1 \mathrm{~g} \cdot$ plant $^{-1}$ where application of $180 \mathrm{~kg} \cdot \mathrm{ha}^{-1}$ of PPB-N produced the smallest plant biomass. Numerically the dry biomass of corn that did not receive any $\mathrm{N}$, corn fertilized with any $\mathrm{PPB}$, and corn fertilized with any urea was 38.3, $26.9-41.1$ and $38.1-40.92 \mathrm{~g} \cdot$ plant $^{-1}$ respectively. Nitrogen concentration in corn plants ranged $6.2-11.5 \mathrm{~g} \cdot \mathrm{kg}^{-1}$. Nitrogen concentration in corn that did not receive any urea or corn that received urea was $8.7-11.5 \mathrm{~g} \cdot \mathrm{kg}^{-1}$ and was significantly more than corn treated with any PPB. Total $\mathrm{N}$ uptake (removed from soil) by the corn plant was $166-455$ mg.plant ${ }^{-1}$. Total $\mathrm{N}$ uptake by corn that did not receive any $\mathrm{N}$, corn fertilized with any PPB, and corn fertilized with any urea were 327, 166 - 278, and 379 $455 \mathrm{mg} \cdot$ plant $^{-1}$ respectively. The data suggest that the high $\mathrm{C} / \mathrm{N}$ ratio (27.2) of PPB resulted in immobilization of PPB-N. Thus the next step will be to research the optimal rates of inorganic $\mathrm{N}$ that should be incorporated into this PPB to reduce its $\mathrm{C}: \mathrm{N}$ to make it an effective high organic matter content $\mathrm{N}$ fertilizer. Nitrogen treatment significantly $(P<0.0001)$ influenced soil organic matter (SOM) which ranged $18.5-19.7 \mathrm{~g} \cdot \mathrm{kg}^{-1}$. The SOM of the treatments 
fertilized with 90 and $180 \mathrm{~kg} \cdot \mathrm{ha}^{-1}$ of PPB-N was $19.4-19.7 \mathrm{~g} \cdot \mathrm{kg}^{-1}$ and was significantly higher than soil that did not receive any $\mathrm{N}$. The application of PPB significantly increased the soil total $C$ which was 36.0 and $23.6 \mathrm{~g} \cdot \mathrm{kg}^{-1}$ in the soil amended with $180 \mathrm{~kg} \cdot \mathrm{ha}^{-1}$ of PPB-N and the control respectively. The observed increase in SOM and total C in PPB treated soil points to the potential soil health and $\mathrm{C}$ sequestration benefits of $\mathrm{PPB}$ provided that its $\mathrm{C} / \mathrm{N}$ ratio can be increased by incorporating inorganic $\mathrm{N}$ into it.

\section{Keywords}

Pelleted Papermill Biosolids, Corn, Nitrogen, Urea, Beneficial Use

\section{Introduction}

Paper production is a major industry, makes significant contribution to the US economy and generates approximately 5.3 million metric tons of wastewater solids [1]. Beneficial utilization of industrial and agricultural byproducts provides a unique opportunity to reduce the overall production cost and increase environmental sustainability. Developing beneficial uses for papermill biosolids $(\mathrm{PB})$ is an example of this environmentally and economically sound approach. The PB is a mixture of organic compounds such as lignin, cellulose, hemicellulose and secondary treated $\mathrm{PB}$ contains $\mathrm{N}, \mathrm{P}$ and additional nutrients. Camberato et al. [2] [3] reported median $\mathrm{N}$ and $\mathrm{P}$ values of 23.3 and $4.2 \mathrm{~g}^{\mathrm{kg}} \mathrm{kg}^{-1}$ respectively for a secondary $\mathrm{PB}$. The organic $\mathrm{C}$, total $\mathrm{N}$, and total $\mathrm{P}$ content of a secondary treated $\mathrm{PB}$ was reported to be $238,26.7$, and $15.3 \mathrm{~g} \cdot \mathrm{kg}^{-1}$ respectively [4]. The total C, N, and P content of $276,3,11.9 \mathrm{~g} \cdot \mathrm{kg}^{-1}$ respectively have been reported [5]. Ziadi et al., [6] reported that the total $\mathrm{C}$ content of two combined (primary and secondary) $\mathrm{PB}$ from Canada were 672 and $438 \mathrm{~g} \cdot \mathrm{kg}^{-1}$ and total $\mathrm{N}$ content the same PBs was 11 and $32 \mathrm{~g} \cdot \mathrm{kg}^{-1}$. However, $\mathrm{PB}$ from a facility that used a deinking process contained 294 and $4.5 \mathrm{~kg}^{-1}$ of total $\mathrm{C}$ and $\mathrm{N}$ respectively. This data clearly indicate that plant nutrients $(\mathrm{N}, \mathrm{P})$ and organic matter content of $\mathrm{PB}$ is determined by the feedstock and paper production process and thus are quite variable [2] [3]. This variability highlights the need for evaluation of each specific type of PB for development of a successful beneficial application program.

The effect of various PB on crop and soil has been investigated in field and greenhouse studies with a variety of crops. Application of a PB with a C:N ratio of 14 increased the yield and $\mathrm{N}$ uptake of barley (Hordem vulgare L.), but application of another $\mathrm{PB}$ with the C:N ratio of 31 did not significantly influence the dry bean (Phaseolus vulgare L.) yield [6]. Anion exchange extractable soil $\mathrm{NO}_{3}-\mathrm{N}$ was immobilized by application of deinking PB with C:N of 65 and increased with application of combined (primary and secondary treated) $\mathrm{PB}$ with C:N ratio of 14 [6]. Application of $100 \mathrm{Mg} \cdot \mathrm{ha}^{-1}$ primary treated PB with the C:N of 86 reduced barley yield as compared to treatment that did not received any PB [7]. 
Application of $120 \mathrm{Mg} \cdot \mathrm{ha}^{-1}$ of a PB with a C:N ratio 10.6 significantly increased the soil mineral $\mathrm{N}$ as compared to the untreated soil. In general application of $\mathrm{PB}$ with high C:N ratio had resulted in immobilization of $\mathrm{N}$ and application of low C:N ratio PB increased soil inorganic $\mathrm{N}$ [4] [8]. The C:N ratio of the PB plays an important role in crop response to $\mathrm{PB}$ application. Most researchers suggested that $\mathrm{C}: \mathrm{N}>30$ will negatively impact crop yield potential and some have reported acritical C:N ratio of 20 - 30 [9] [10].

Several Researchers have reported that application of $\mathrm{PB}$ had increased soil organic $\mathrm{C}$ content with the amount of increase in soil $\mathrm{C}$ being dependent on $\mathrm{PB}$ composition, processing, and application rate [3] [11] [12]. As an example, application of 40,80 , and $120 \mathrm{Mg} \cdot \mathrm{ha}^{-1}$ of secondary treated pulp mill sludge increased the organic $\mathrm{C}$ in a soils by $0.4,0.6$, and $1.3 \mathrm{~g} \cdot \mathrm{kg}^{-1}$ respectively [4].

These studies clearly demonstrate that soil and plant response to $\mathrm{PB}$ is dependent on several factors including the nature of the $\mathrm{PB}$, application rate, and crop grown. Thus the development of an economically and environmentally successful beneficial use of PB requires information on crop and soil response to $\mathrm{PB}$ when it is applied at agronomically reasonable rates.

Despite the environmental and economic benefits of beneficial use of $\mathrm{PB}$, a small percentage of total amount of PB produced in US is currently utilized as a beneficial soil amendment. The difficulties in long distance transport and field application (requiring specialized equipment) are two major hindrances. Pelletization of PB is an effective means to overcome those obstacles. Cooperative efforts in the US have resulted in successful development of a pelleted papermill biosolids (PPB) which is a mixture of $\mathrm{PB}$ and byproduct of cow manure. This newly developed PPB is currently at testing stage of product development. The objectives of this research were to measure and compare the effects of several rates of PPB, urea, a $0 \mathrm{~N}$ control on corn: 1) plant height 2) $\mathrm{N}$ concentration and uptake, 3) selected soil properties.

\section{Experimental Procedures}

In 2017 a replicated greenhouse experiment was conducted at the University of Arkansas Northeast Research and Extension Center (NEREC) in Keiser Arkansas ( $\left.\mathrm{N}: 35.674988^{\circ}, \mathrm{W}:-90.084732^{\circ}\right)$. The study evaluated corn and soil response to urea and PPB each applied at four total $\mathrm{N}$ rates equivalent to $45,90,135$, and $180 \mathrm{~kg}$ total $\mathrm{N} \mathrm{ha}^{-1}$. The PPB applications rates were approximately equivalent to $2.24,4.48,6.72$, and $8.48 \mathrm{Mg} \cdot \mathrm{ha}^{-1}$ of PPB on as is basis. A control treatments of 0 $\mathrm{N}$ was also included. Detailed experimental treatments are listed in Table 1. Experimental design was a randomized complete block, each treatment was replicated five times.

\subsection{Greenhouse Cropping}

A bulk sample of the $0-15 \mathrm{~cm}$ depth of a soil mapped as Deerfield loamy fine sand (mixed, mesic Aquic Udipsamments) was collected, dried to constant 
Table 1. Nitrogen sources, total $\mathrm{N}$ application rates, and eight $\mathrm{N}$-treatments for a corn experiment conducted under controlled greenhouse environment at the University of Arkansas Northeast Research and Extension Center in Keiser, Arkansas in 2017.

\begin{tabular}{cccc}
\hline N source & $\begin{array}{c}\text { Amendment rate } \\
\left(\mathrm{kg}^{-h^{-1}}\right)\end{array}$ & $\begin{array}{c}\text { Total N rate } \\
\left(\mathrm{kg} \mathrm{N} \mathrm{ha}^{-1}\right)\end{array}$ & N-treatment \\
\hline None & 0 & 0 & none \\
Urea & 98 & 45 & Urea-45 \\
Urea & 195 & 90 & Urea-90 \\
Urea & 292 & 135 & Urea-135 \\
Urea & 382 & 180 & Urea-180 \\
PPB & 2240 & 45 & PPB-45 \\
PPB & 4480 & 90 & PPB-90 \\
PPB & 6720 & 135 & PPB-135 \\
PPB & 8480 & 180 & PPB-180 \\
\hline
\end{tabular}

moisture in a forced-air oven at $40^{\circ} \mathrm{C}$, and ground to pass a 2-mm sieve. Dried soil sample was thoroughly mixed in a new cement mixer. Soil $\mathrm{pH}$ was measured by 1:1 soil:water [13] and soil organic matter (SOM) was measured gravimetrically by loss on ignition (LOI) [14]. Soil total $\mathrm{C}$ and $\mathrm{N}$ were measured by combustion using an Elementar Variomax instrument [15]. Soil $\mathrm{NO}_{3}-\mathrm{N}$ and $\mathrm{NH}_{4}-\mathrm{N}$ were extracted by $2-\mathrm{M} \mathrm{KCl}$ and measured on a Skalar auto analyzer [16]. Those two are the inorganic sources of soil $\mathrm{N}$ which are taken up by plants. Mehlich-3 extractable nutrients were measured by the standard procedure [17]. Relative amount of sand, silt, and clay were measured by the hydrometer method [18]. The PPBwas ground to fineness in a new coffee grinder and analyzed for $\mathrm{pH}$, total $\mathrm{C}$, total $\mathrm{N}, \mathrm{NO}_{3}-\mathrm{N}$, and $\mathrm{NH}_{4}-\mathrm{N}$ as described. Total $\mathrm{P}$ and total $\mathrm{K}$ were measured by standard method and converted to $\mathrm{P}_{2} \mathrm{O}_{5}$ and $\mathrm{K}_{2} \mathrm{O}$ equivalents [19].

We amended the bulk soil sample with monocalcium phosphate $\left(\left(\mathrm{CaH}_{2} \mathrm{PO}_{4}\right)_{2}\right)$, potassium chloride $(\mathrm{KCl})$, sulfate of potash and magnesia (Sul-Po-Mag), zinc sulfate $\left(\mathrm{ZnSO}_{4}\right)$ and pelletized lime to supply the equivalent of $56,112,36,48$, 8.4, and $2800 \mathrm{~kg} \cdot \mathrm{ha}^{-1}$ of: $\mathrm{P}_{2} \mathrm{O}_{5}, \mathrm{~K}_{2} \mathrm{O}, \mathrm{Mg}, \mathrm{S}, \mathrm{Zn}$, and lime respectively. This ensured that $\mathrm{N}$ was the only soil amendment that could limit the corn yield potential.

The experimental units consisted of 24-cm diameter-7.2-liter black plastic pots. The required amount of $\mathrm{N}$ source for all five replications of each treatment was thoroughly mixed with the appropriate quantity of soil in a cement mixer. Then $9 \mathrm{~kg}$ of N-treated soil was transferred into each plastic pot and the pot was tamped three times to create a uniform soil bulk density. Five seeds of corn hybrid DEKALB "DK C67-14", a high biomass producing hybrid, were planted in each pot on 5-July 2017 and thinned to one seedling per pot five days after germination. Greenhouse temperature was set to maintain at $24^{\circ} \mathrm{C}$. Supplemental light was provided $12 \mathrm{hrs} \cdot \mathrm{day}^{-1}$ from 7:00 AM to 7:00 pm and corn was watered 
as needed. Corn was grown for 77 days and the experiment was terminated on 19-September 2017 when most plants had reached the silk growth stage (R-1).

\subsection{Corn and Soil Sample Collection and Analysis}

At the end of the study we measured and recorded the height of each corn plant from the lowest node above the soil level to the top of the tassel and cut the total above-ground portion of each plant at $1 \mathrm{~cm}$ above the soil level. Plant samples were dried to constant weight in a forced-air oven and plant dry biomass was recorded. Plant samples from all five replications were ground in a Willey Mini-Mill to pass a 20-mesh sieve and analyzed for total $\mathrm{N}$ with combustion method. Total $\mathrm{N}$ uptake per plant was calculated by multiplying the whole plant biomass by its respective $\mathrm{N}$ concentration.

After the corn harvest we transferred the soil from each pot (selected N-treatments: 0,90 and $180 \mathrm{~kg}$ total $\mathrm{N} \mathrm{ha}^{-1}$ ) to a clean plastic tub, removed the roots manually, mixed the soil thoroughly, and collected representative samples by the quarter method. Postharvest samples were ground to pass a 2-mm-sieve and analyzed for $\mathrm{pH}$, total $\mathrm{N}, \mathrm{NH}_{4}-\mathrm{N}, \mathrm{NO}_{3}-\mathrm{N}$, and $\mathrm{SOM}$ as described before.

\subsection{Statistical Analysis}

We performed analysis of variance (ANOVA) to evaluate and compare the effect of $\mathrm{N}$-treatment on corn growth parameters and post-harvest soil properties using the SAS software package. When appropriate, means were separated by the least significant difference (LSD) method and interpreted as significant when $P \leq$ 0.10 .

\section{Results and Discussion}

\subsection{Characterization of Soil and $\mathrm{N}$-Sources}

Prior to addition of any soil amendment, the soil pH was 5.5 and SOM was 28 $\mathrm{g} \cdot \mathrm{kg}^{-1}$ (Table 2). Soil texture was sandy loam; sand and clay were the most and least predominant soil particles respectively. Soil inorganic $\mathrm{N}$ was $13.2 \mathrm{mg} \cdot \mathrm{kg}^{-1}$ and $\mathrm{NH}_{4}-\mathrm{N}$ was the predominant form. Mehlich-3 extractable $\mathrm{K}$ was $28 \mathrm{mg} / \mathrm{kg}$ indicating the need for supplemental $\mathrm{K}$ fertilization.

The PPB had a $\mathrm{pH} 7.7$ which is within the range of values reported by Price et al. (2009) [5] and Ziadi et al. (2013) [6]. Carbon and N concentrations were 379 and $14 \mathrm{~g} \cdot \mathrm{kg}^{-1}$ respectively and C:N ratio was 27.2 (Table 3 ). The $\mathrm{C}$ and $\mathrm{N}$ concentrations of 276 and $3 \mathrm{mg} \cdot \mathrm{kg}^{-1}$ and C:N ratio of 92 respectively have been reported by others [5]. The $\mathrm{C}$ and $\mathrm{N}$ concentrations of 329 - 438, 10.5 - 315 $\mathrm{mg} \cdot \mathrm{kg}^{-1}$ and C:N of $14-31$ for two secondary treated PPB have been reported [6].

Nitrate- $\mathrm{N}$ was below the detection limit and $\mathrm{NH}_{4}-\mathrm{N}$ was very low $\left(0.18 \mathrm{~g} \cdot \mathrm{kg}^{-1}\right)$ indicating that organic $\mathrm{N}$ was the predominant source of $\mathrm{N}$. Therefore, $\mathrm{N}$ mineralization/immobilization is expected to be the key determinant of the $\mathrm{N}$ fertilizer value of PPB. The PPB contained several plant essential nutrients including 
Table 2. Selected mean $(n=2)$ properties of the thoroughly mixed untreated bulk soil sample of the surface horizon of a Deerfield loamy fine sand that was used for the greenhouse study at the University of Arkansas Northeast Research and Extension Center, in Keiser, Arkansas in 2017.

\begin{tabular}{|c|c|c|c|c|c|c|c|c|c|c|c|c|}
\hline \multirow[t]{2}{*}{ Soil pH } & \multirow[t]{2}{*}{ Sand } & \multirow{2}{*}{ Silt } & \multirow{2}{*}{ Clay } & \multirow{2}{*}{$\begin{array}{c}\text { Soil } \\
\text { Organic } \\
\text { Matter }\end{array}$} & \multirow{2}{*}{ Total C } & \multirow{2}{*}{ Total N } & \multirow{2}{*}{$\mathrm{NO}_{3}-\mathrm{N}$} & \multirow{2}{*}{$\mathrm{NH}_{4}-\mathrm{N}$} & \multicolumn{4}{|c|}{$\begin{array}{c}\text { Mehlich-3-extractable } \\
\text { nutrients }\end{array}$} \\
\hline & & & & & & & & & $\mathrm{P}$ & $\mathrm{K}$ & $\mathrm{Ca}$ & $\mathrm{Mg}$ \\
\hline & & & & $\mathrm{g} \cdot \mathrm{kg}^{-1}$ & & & & & $\mathrm{~g} \cdot \mathrm{kg}^{-1}$ & & & \\
\hline 5.5 & 630 & 300 & 70 & 28 & 12.42 & 0.64 & 1.52 & 11.70 & 75 & 28 & 176 & 25 \\
\hline
\end{tabular}

Table 3. Selected mean properties of the finely ground sample of the pelletized papermillbiosolids (PPB) that was used in a greenhouse study with corn at the University of Arkansas Northeast Research and Extension Center in Keiser, Arkansas in 2017.

\begin{tabular}{cccccccc}
\hline \multirow{2}{*}{ Test Material } & $\mathrm{pH}$ & Total C & Total N & $\mathrm{C} / \mathrm{N}$ ratio & $\mathrm{NH}_{4}-\mathrm{N}$ & $\mathrm{P}_{2} \mathrm{O}_{5}$ & $\mathrm{~K}_{2} \mathrm{O}$ \\
\cline { 2 - 7 } & & \multicolumn{7}{c}{$\mathrm{g} \cdot \mathrm{kg}^{-1}$} \\
\hline $\begin{array}{c}\text { Pelletized papermill } \\
\text { biosolids (PPB) }\end{array}$ & 7.7 & 378.7 & 13.9 & 272 & 0.18 & 5.0 & 6.8 \\
\hline
\end{tabular}

(P) and potassium (K), thus it is a potential low grade and high organic matter source of those two nutrients.

\subsection{Corn Response to $\mathrm{N}$-Treatment}

Nitrogen treatment did not significantly influence $(P \geq 0.1)$ plant height which numerically ranged $175-183 \mathrm{~cm}$ (Table 4). However, it significantly $(P<$ 0.0001 ) affected corn dry biomass, $\mathrm{N}$ concentration, and $\mathrm{N}$ uptake. Corn dry biomass ranged 26.9 - 41.1 g.plant ${ }^{-1}$. Dry biomass of corn that did not receive any $\mathrm{N}$ was $38.3 \mathrm{~g} \cdot$ plant $^{-1}$ and was not significantly different than urea- $\mathrm{N}$ treated corn (38.1 - 40.9 g.plant $\left.^{-1}\right)$ or corn treated with $90 \mathrm{~kg}$ PPB-N ha ${ }^{-1}$. Application of $180 \mathrm{~kg} \cdot \mathrm{ha}^{-1}$ of PPB-N produced the significantly smallest plant biomass (26.9 g.plant ${ }^{-1}$ ). Application of $\geq 135 \mathrm{~kg}$ PPB- $\mathrm{N} \mathrm{ha}^{-1}$ significantly reduced the corn dry biomass as compared to lower rates of $\mathrm{PPB}, 0-\mathrm{N}$, or urea- $\mathrm{N}$ treatments. There was a trend of decreasing plant biomass with increasing PPB rate. This is consistent with Gagnon et al. (2012) [20] who reported corn dry biomass of 9.7, and $14 \mathrm{Mg} \cdot \mathrm{ha}^{-1}$ for plants that received $150 \mathrm{~kg} \mathrm{~N} \mathrm{ha}{ }^{-1}$ from $\mathrm{PB}$ and mineral fertilizer respectively. It is also similar to the effect of a deinking $\mathrm{PB}$, where increasing the $\mathrm{PB}$ application rate decreased the dry biomass of perennial ryegrass ( $\mathrm{Lo}$ lium Perrenne) (Simard et al., 1998) [21]. However, N'Dayegamiye et al.

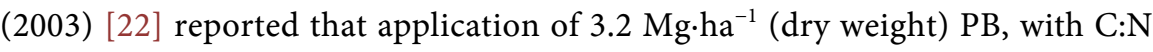
ratio of 14 , significantly increased corn dry biomass as compared to $0 \mathrm{~N}$ control. In our study corn amended with high PPB rates exhibited visual symptoms consistent with $\mathrm{N}$ deficiency (yellowing of the lower leaves). The difference between our results and theirs can be attributed to the wider C:N ratio of the PPB we used (14 vs. 27.2). We believe that the wide C:N ratio (27.2) of our PPB 
Table 4. Effect of urea, and pelletized Papermill biosolids (PPB) on plant height, whole plant dry biomass, $\mathrm{N}$ concentration, and total $\mathrm{N}$ uptake by corn plants in the greenhouse study conducted at the University of Arkansas Northeast Research and Extension Center in Keiser, Arkansas in 2017.

\begin{tabular}{ccccccc}
\hline N source & $\begin{array}{c}\text { Total N-rate } \\
\left(\mathrm{kg} \cdot \mathrm{ha}^{-1}\right)\end{array}$ & N-treatment & $\begin{array}{c}\text { Plant height } \\
(\mathrm{cm})\end{array}$ & $\begin{array}{c}\text { Plant dry } \\
\text { biomass } \\
\left(\mathrm{g} \cdot \mathrm{plant}^{-1}\right)\end{array}$ & $\begin{array}{c}\mathrm{N} \\
\text { concentration } \\
\left(\mathrm{g} \cdot \mathrm{kg}^{-1}\right)\end{array}$ & $\begin{array}{c}\text { N uptake } \\
\left(\mathrm{mg} \mathrm{N}_{\mathrm{plant}} \mathrm{f}^{-1}\right)\end{array}$ \\
\hline None & 0 & none & $179 \mathrm{a}^{\mathrm{z}}$ & $38.3 \mathrm{ab}$ & $8.7 \mathrm{~b}$ & $327 \mathrm{bc}$ \\
Urea & 45 & Urea-45 & $175 \mathrm{a}$ & $40.9 \mathrm{a}$ & $9.5 \mathrm{~b}$ & $379 \mathrm{ab}$ \\
Urea & 90 & Urea-90 & $178 \mathrm{a}$ & $38.1 \mathrm{ab}$ & $10.2 \mathrm{ab}$ & $388 \mathrm{ab}$ \\
Urea & 135 & Urea-135 & $175 \mathrm{a}$ & $39.1 \mathrm{ab}$ & $11.5 \mathrm{a}$ & $455 \mathrm{a}$ \\
Urea & 180 & Urea-180 & $183 \mathrm{a}$ & $39.5 \mathrm{ab}$ & $10.1 \mathrm{ab}$ & $421 \mathrm{a}$ \\
PPB & 45 & PPB-45 & $178 \mathrm{a}$ & $41.1 \mathrm{a}$ & $6.7 \mathrm{c}$ & $278 \mathrm{~cd}$ \\
PPB & 90 & PPB-90 & $180 \mathrm{a}$ & $36.9 \mathrm{ab}$ & $6.7 \mathrm{c}$ & $245 \mathrm{~d}$ \\
PPB & 135 & PPB-135 & $180 \mathrm{a}$ & $32.7 \mathrm{c}$ & $6.3 \mathrm{c}$ & $210 \mathrm{de}$ \\
PPB & 180 & PPB-180 & $179 \mathrm{a}$ & $26.9 \mathrm{~d}$ & $6.2 \mathrm{c}$ & $166 \mathrm{e}$ \\
$P$ value & & & 0.9858 & $<0.0001$ & $<0.0001$ & $<0.0001$ \\
\hline
\end{tabular}

${ }^{7}$ means followed by the same letter are not significantly different at $P$ value $=0.10$.

promoted immobilization of soil and PPB-N. Several researchers have noted that application of $\mathrm{PB}$ with $\mathrm{C}: \mathrm{N}$ ratio $>30$ can result in microbial sequestration of $\mathrm{N}$ in soil [7] [23] [24]. Some other researchers, have noted a critical C:N ratio of 12 - 30 [12]. Our data indicates that $\mathrm{N}$ immobilization occurred at the C:N ratio of 27.2 .

From a beneficial use perspective, the $\mathrm{C} / \mathrm{N}$ ratio of the $\mathrm{PPB}$ can be reduced by incorporating inorganic $\mathrm{N}$ (from a nitrogen fertilizer) into the pellets. This approach have been tested by several researchers with generally successful outcomes [25] [26] [27].

Nitrogen concentration in corn ranged $6.2-11.5 \mathrm{~g} \cdot \mathrm{kg}^{-1}$ and there was no significant difference in $\mathrm{N}$ concentration between plants that did not received any $\mathrm{N}\left(8.7 \mathrm{~g} \cdot \mathrm{kg}^{-1}\right)$ and plants fertilized with 45 or $90 \mathrm{~kg}$ urea-N ha ${ }^{-1}(9.5-10.2$ $\left.\mathrm{g} \cdot \mathrm{kg}^{-1}\right)$. However, $\mathrm{PPB}$ application significantly reduced corn $\mathrm{N}$ concentration as compared with the corn that did not receive any $\mathrm{N}\left(6.2-6.7 \mathrm{vs} 8.7 \mathrm{~g} \cdot \mathrm{kg}^{-1}\right)$. On average the application of PPB reduced the corn $\mathrm{N}$ concentration by $26 \%$ as compared to the corn that did not receive any $\mathrm{N}$. At any given $\mathrm{N}$ application rate, the $\mathrm{N}$ concentration of urea- $\mathrm{N}$ treated corn was significantly more than PPB-N treated corn. Increasing PPB application rate often numerically albeit not significantly reduced corn $\mathrm{N}$ concentration. This is in agreement with Simmard et al. [21] who reported that increasing PB application rate decreased $\mathrm{N}$ concentration in barley grain and straw. Similar results were reported by Feagly et al. (1994) [28] and Douglass et al. (2003) [29]. The trend in our corn N concentration indicates $\mathrm{N}$ immobilization by PPB application. 
Total $\mathrm{N}$ uptake (removed from soil) by the corn plant reflected corn dry biomass and $\mathrm{N}$ concentration. Total $\mathrm{N}$ uptake by corn that did not receive any $\mathrm{N}$ and corn fertilized with urea-N or PPB-N were 327, 166 - 278, and $379-455$ mg.plant ${ }^{-1}$ respectively. This is in agreement with Gagnon et al. (2012) [20] who noted that $\mathrm{N}$ uptake by silage corn fertilized with $150 \mathrm{~kg}$ inorganic $\mathrm{N} \mathrm{ha}^{-1}$ was significantly more than corn that received the same amount of total $\mathrm{N}$ from a PB with C:N ratio of 50. Nitrogen uptake by any urea treated corn was significantly more than corn treated with any PPB. There was no significant difference in $\mathrm{N}$ uptake among the plants that did not receive any $\mathrm{N}$ and those fertilized with 45 or $90 \mathrm{~kg}$ urea-N ha ${ }^{-1}$. Plants treated with $180 \mathrm{~kg} \cdot \mathrm{ha}^{-1}$ urea-N were very dark green, a symptom consistent with excessive $\mathrm{N}$ uptake.

\subsection{Post-Harvest Soil Samples}

Nitrogen treatment did not significantly influence the soil $\mathrm{pH}(P>0.1$, Table 5$)$, but significantly $(P<0.0001)$ influenced SOM which ranged $18.5-19.7 \mathrm{~g} \cdot \mathrm{kg}^{-1}$. The SOM of the treatments that received 90 and $180 \mathrm{~kg}$ PPB-N ha ${ }^{-1}$ were 19.7 and $19.4 \mathrm{~g} \cdot \mathrm{kg}^{-1}$ respectively and were significantly higher than soil that did not receive any $\mathrm{N}\left(\mathrm{SOM}=18.5 \mathrm{~g} \cdot \mathrm{kg}^{-1}\right)$. This is a small increase in $\mathrm{SOM}$, however the amount of PPB applied at those two rates (Table 1) was $\leq 8480 \mathrm{~kg} \cdot \mathrm{ha}^{-1}$ which is considered a low rate. The observed increase in SOM, brought about by PPB, points to the potential soil health benefits of beneficial use of higher rates of $\mathrm{PPB}$, provided that its $\mathrm{C}: \mathrm{N}$ ratio can be reduced to control $\mathrm{N}$-immobilization. Nitrogen treatment significantly $(P<0.0001)$ influenced soil total $\mathrm{C}$ and $\mathrm{N}$. Total $\mathrm{C}$ in the soil that did not receive any $\mathrm{N}$ was $23.6 \mathrm{~g} \cdot \mathrm{kg}^{-1}$ and that of the soil treated with $180 \mathrm{~kg} \mathrm{~N} \mathrm{ha}{ }^{-1}$ by urea or PPB were 33.4 and $36.0 \mathrm{~g} \cdot \mathrm{kg}^{-1}$ respectively. The increase in soil C is consistent with Rotenberg et al. (2005) [30] where application of secondary PB increased soil organic C. Similar to the increase in SOM, amending soil with PPB is a potential means of $\mathrm{C}$ sequestration and thus it is environmentally appealing.

Table 5. Effect of urea and pelletized Papermill biosolids (PPB), each applied at two total $\mathrm{N}$ rates on selected chemical properties of the soil samples taken from experimental pots after corn harvest in the greenhouse study conducted at the University of Arkansas Northeast Research and Extension Center in Keiser, Arkansas in 2017.

\begin{tabular}{|c|c|c|c|c|c|c|c|}
\hline \multirow{2}{*}{$\mathrm{N}$ source } & Total N-rate & \multirow{2}{*}{ Soil pH } & Soilorganic matter & Total C & Total N & $\mathrm{NH}_{4}-\mathrm{N}$ & $\mathrm{NO}_{3}-\mathrm{N}$ \\
\hline & lb N/acre & & \multicolumn{3}{|c|}{$\mathrm{g} \cdot \mathrm{kg}^{-1}$} & \multicolumn{2}{|c|}{$\mathrm{mg} \cdot \mathrm{kg}^{-1}$} \\
\hline None & 0 & $6.1 b^{z}$ & $18.5 \mathrm{~b}$ & $23.6 \mathrm{~b}$ & $2.1 \mathrm{a}$ & $0.31 b$ & $6.7 \mathrm{c}$ \\
\hline Urea & 90 & $6.0 \mathrm{~b}$ & $18.0 \mathrm{~b}$ & $21.6 \mathrm{~b}$ & $1.8 \mathrm{~b}$ & $0.49 b$ & $14.6 \mathrm{~b}$ \\
\hline Urea & 180 & $6.0 \mathrm{~b}$ & $19.6 a$ & $33.4 \mathrm{a}$ & $1.3 \mathrm{c}$ & $2.29 \mathrm{a}$ & $20.2 \mathrm{a}$ \\
\hline РPB & 90 & $6.5 b$ & $19.7 \mathrm{a}$ & $23.3 \mathrm{~b}$ & $1.8 \mathrm{ab}$ & $0.18 b$ & $1.6 \mathrm{~d}$ \\
\hline PPB & 180 & $6.2 b$ & $19.4 \mathrm{a}$ & $36.0 \mathrm{a}$ & $1.1 \mathrm{c}$ & $0.27 b$ & $2.1 \mathrm{~d}$ \\
\hline \multicolumn{2}{|r|}{$P$ value } & 0.1112 & $<0.0001$ & $<0.0001$ & 0.0001 & $<0.0001$ & $<0.0001$ \\
\hline
\end{tabular}

${ }^{z}$ means followed by the same letter are not significantly different at $P$ value $=0.10$. 
Total $\mathrm{N}$ in post-harvest soil samples ranged $1.1-2.1 \mathrm{~g} \cdot \mathrm{kg}^{-1}$ where the highest and lowest total $\mathrm{N}$ were measured in soil that did not receive any $\mathrm{N}$ and soil treated with $180 \mathrm{~kg} \cdot \mathrm{ha}^{-1}$ of $\mathrm{PPB}-\mathrm{N}$ respectively. The inorganic forms of $\mathrm{N}$ $\left(\mathrm{NH}_{4}-\mathrm{N}\right.$ and $\left.\mathrm{NO}_{3}-\mathrm{N}\right)$ were significantly $(P<0.0001)$ affected by $\mathrm{N}$-treatment. Nitrate- $\mathrm{N}$ was the predominant form of soil inorganic $\mathrm{N}\left(1.6-20.2 \mathrm{mg} \mathrm{NO}_{3}-\mathrm{N}\right.$ $\left.\mathrm{kg}^{-1}\right)$ as compared to $\mathrm{NH}_{4}-\mathrm{N}\left(0.18-2.29 \mathrm{mg} \mathrm{NH}_{4}-\mathrm{N} \mathrm{kg}^{-1}\right)$. Soil $\mathrm{NH}_{4}-\mathrm{N}$ was highest in soil that was treated with $180 \mathrm{~kg} \cdot \mathrm{ha}^{-1}$ urea-N perhaps as a result of hydrolysis of urea in soil. Nitrate- $\mathrm{N}$ concentration was highest in the urea treated soil (14.6 - $20.2 \mathrm{mg} \mathrm{NO}_{3}-\mathrm{N} \mathrm{kg}^{-1}$ ), lowest in soil treated with $\mathrm{PPB}\left(1.6-2 \mathrm{mg} \mathrm{\textrm {NO } _ { 3 } - \mathrm { N }}\right.$ $\mathrm{kg}^{-1}$ ), and that of soil that did not receive any $\mathrm{N}$ was $6.7 \mathrm{mg} \cdot \mathrm{kg}^{-1}$. The low concentration of $\mathrm{NO}_{3}-\mathrm{N}$ in PPB treated soil is another indicator of microbial sequestration of PPB-N.

\section{Concluding Remarks}

The outcome of this research suggests that PPB is a good source of organic matter, will improve soil health and enhance $\mathrm{C}$ sequestration. However, its $\mathrm{C}: \mathrm{N}$ ratio needs to be reduced such that it can supply $\mathrm{N}$ to a growing crop of corn. Therefore, future research with this PPB should focus on evaluating the optimal rate of supplemental $\mathrm{N}$ that should be added to make it an effective source of $\mathrm{N}$.

\section{Conflicts of Interest}

The authors declare no conflicts of interest regarding the publication of this paper.

\section{References}

[1] Feldkinchner, D., Wang, C., Gower, S., Kruger, E. and Ferris, J. (2003) Effects of Nutrient and Papermill Biosolids Amendment on Growth and Nutrient Status of Hardwood Forest. Forest Ecology and Management, 177, 95-116.

https://doi.org/10.1016/S0378-1127(02)00318-3

[2] Camberato, J.J., Vance, E.D. and Someshwar, A.V. (1997) Composition and Land Application of Paper Manufacturing Residuals. In: Rechcigl, J.E. and MacKinnon, H.C., Eds., Agricultural Uses of by-Products and Wastes, American Chemical Society Symposium Series 668, Washington DC, 185-202.

https://doi.org/10.1021/bk-1997-0668.ch012

[3] Camberato, J.J., Gagnon, B., Angers, D.A., Chantigny, M.H. and Pan, W.L. (2006) Pulp and Papermill by-Products as Soil Amendments and Plant Nutrient Sources. Canadian Journal of Soil Science, 86, 641-653. https://doi.org/10.4141/S05-120

[4] Nunes, J.R., Cabral, F. and Lòpez-Piñeiro, F.A. (2008) Short Term Effects on Soil Properties and Wheat Production from Secondary Paper Sludge Application on Two Mediterranean Agricultural Soils. Bioresource Technology, 99, 935-4942. https://doi.org/10.1016/j.biortech.2007.09.016

[5] Price, G.W., Voroney, R.P. and Chong, C. (2009) Crop Performance on Soils Receiving Annual Papermill Biosolid Amendments with and without Supplementary Nitrogen. Canadian Journal of Soil Science, 89, 269-279. https://doi.org/10.4141/CJSS08014 
[6] Ziadi, N., Gagnon, B. and Nyiraneza, J. (2013) Crop Yield and Soil Fertility as Affected by Papermill Biosolids and Liming Byproducts. Canadian Journal of Soil Science, 93, 319-328. https://doi.org/10.4141/cjss2012-129

[7] Aitken, M.N., Evans, B. and Lewis, J.G. (1998) Effect of Applying Papermill Sludge to Arable Land on Soil Fertility and Crop Yields. Soil Use and Management, 14, 215-222. https://doi.org/10.1111/j.1475-2743.1998.tb00153.x

[8] Cabral, F. and Vasconcelos, E. (1993) Agricultural Use of Combined Primary/Secondary Pulpmill Sludge. Agrochimica, 37, 409-417.

[9] Cordovil, C., Cabral, F. and Coutinho, J. (2007) Potential Mineralization of Nitrogen from Organic Wastes to Ryegrass and Wheat Crops. Bioresource Technology, 98, 3265-3268. https://doi.org/10.1016/j.biortech.2006.07.014

[10] Sims, J.T. (1990) Nitrogen Mineralization and Elemental Availability in Soils Amended with Composted Sewage Sludge. Journal of Environmental Quality, 19, 669-675. https://doi.org/10.2134/jeq1990.00472425001900040007x

[11] Levy, J.S. and Taylor, B.R. (2003) Effects of Pulpmill Solids and Three Composts on Early Growth of Tomatoes. Bioresource Technology, 89, 297-305. https://doi.org/10.1016/S0960-8524(03)00065-8

[12] Battaglia, A., Calaces, N., Nardi, E., Petronio, B. and Pietrotti, M. (2007) Reduction of $\mathrm{Pb}$ and $\mathrm{Zn}$ Bioavailable Forms in Metal Polluted Soils Due to Papermill Sludge Addition. Effects on $\mathrm{Pb}$ and $\mathrm{Zn}$ Transferability to Barley. Bioresource Technology, 98, 2293-2999. https://doi.org/10.1016/j.biortech.2006.10.007

[13] Sikora, F. and Kissel, D. (2014) Soil pH. In: Sikora, F.J. and Moore, K.P., Eds., Soil Test Methods from the Southeastern United States, University of Georgia, Athens, GA, 48-53. http://aesl.ces.uga.edu/sera6/PUB/MethodsManualFinalSERA6.asp

[14] Zhang, H. and Wang, J.J. (2014) Loss on Ignition. In: Sikora, F.J. and Moore, K.P., Eds., Soil Test Methods from the Southeastern United States, University of Georgia, Athens, GA, 155-157. http://aesl.ces.uga.edu/sera6/PUB/MethodsManualFinalSERA6.asp

[15] Provin, T. (2014) Total Carbon and Organic Carbon via Thermal Combustion Analyses. In: Sikora, F.J. and Moore, K.P., Eds., Soil Test Methods from the Southeastern United States, University of Georgia, Athens, GA, 149-154. http://aesl.ces.uga.edu/sera6/PUB/MethodsManualFinalSERA6.asp

[16] Miller, R. and Sonon, L. (2014) Nitrate-Nitrogen. In: Sikora, F.J. and Moore, K.P., Eds., Soil Test Methods from the Southeastern United States, University of Georgia, Athens, 136-145. http://aesl.ces.uga.edu/sera6/PUB/MethodsManualFinalSERA6.asp

[17] Zhang, H., Hardy, D.H., Mylavarapu, R. and Wang, J.J. (2014) Mehlich-3. In: Sikora, F.J. and Moore, K.P., Eds., Soil Test Methods from the Southeastern United States, University of Georgia, Athens, GA, 101-110. http://aesl.ces.uga.edu/sera6/PUB/MethodsManualFinalSERA6.asp

[18] Huluka, G. and Miller, R. (2014) Particle Size Determination by Hydrometer Method. In: Sikora, F.J. and Moore, K.P., Eds., Soil Test Methods from the Southeastern United States, University of Georgia, Athens, GA, 48-53. http://aesl.ces.uga.edu/sera6/PUB/MethodsManualFinalSERA6.asp

[19] Peters, J.B. (2003) Recommended Methods of Manure Analysis. https://soils.wisc.edu/extension/pubs/A3769.pdf

[20] Gagnon, B., Ziadi, N., Chantigny, M.H., Bèlanger, G. and Massè, D.I. (2012) Biosolids from Treated Swine Manure and Papermill Residues Affects Corn Fertilizer 
Value. Agronomy Journal, 104, 483-492. https://doi.org/10.2134/agronj2011.0327

[21] Simard, R.R., Baziramakenga, R.S., Yelle, S. and Coulombe, J. (1998) Effects of de-Inking Paper Sludges on Soil Properties and Crop Yields. Canadian Journal of Soil Science, 788, 689-697. https://doi.org/10.4141/S98-003

[22] N'Dayegamiye, A., Haurd, S. and Thibault, Y. (2003) Influence of Papermill Sludge on Corn Yields and N recovery. Canadian Journal of Soil Science, 83, 497-450. https://doi.org/10.4141/S02-077

[23] Norris, M. and Titshall, L. (2010) The Potential for Direct Application of Papermill Sludge to Land: A Greenhouse Study. Proceedings of the 19th World Congress of Soil Science, Brisbane, Australia, 1-6 August 2010, 217-220.

[24] Zibilske, L.M. (1987) Dynamics of Nitrogen and Carbon Mineralization in Soil during Papermill Sludge Decomposition. Soil Science, 143, 26-33. https://doi.org/10.1097/00010694-198701000-00004

[25] Antille, D.L., Sakrabani, R. and Godwin, R.J. (2014) Effects of Biosolids-Derived Organo-Mineral Fertilizers, Urea and Biosolids Granules on Crop and Soil Established with Ryegrass (Lolium perenne L.). Communications in Soil Science and Plant Analysis, 45, 1605-1621. https://doi.org/10.1080/00103624.2013.875205

[26] Smith, G., Chaney, K., Murray, C. and Le, M. (2015) The Effect of Organo-Mineral Fertilizer Applications on the Yield of Winter Wheat, Spring Barley, Forage Maize and Grass Cut for Silage. Journal of Environmental Protection, 6, 103-109. https://doi.org/10.4236/jep.2015.62012

[27] Zebarth, B.J., Chabot, J., Coulombe, J., Simard, R.R., Douheret, J. and Tremblay, N. (2005) Pelletized Organo-Mineral Fertilizer Product as a Nitrogen Source for Potato Production. Canadian Journal of Soil Science, 85, 387-395. https://doi.org/10.4141/S04-071

[28] Feagley, S.E., Valdez, M.S. and Hundall, W.H. (1994) Bleached, Primary Papermill Sludge Effect on Bermudagrass Grown on a Mine Soil. Soil Science, 157, 389-397. https://doi.org/10.1097/00010694-199406000-00008

[29] Douglas, J.T., Aitken, M.N. and Smith, C.A. (2003) Effects of Five Non-Agricultural Organic Wastes on Soil Composition, and on the Yield and Nitrogen Recovery of Italian Ryegrass. Soil Use and Management, 19, 135-138.

[30] Rotenberg, D., Cooperband, L. and Stone, A. (2005) Dynamic Relationship between Soil Properties and Foliar Diseases as Affected by Annual Addition of Organic Amendment to a Sandy Soil Vegetable Production Systems. Soil Biology Biochemistry, 37, 1343-1357. https://doi.org/10.1016/j.soilbio.2004.12.006

\title{
List of Abbreviations
}

\author{
g: Gram \\ mg: Milligram \\ kg: Kilogram \\ PPB: Pelletized Papermill Biosolids \\ SOM: Soil Organic Matter
}

